\title{
Marked genetic structuring in localised spawning populations of cod Gadus morhua in the North Sea and adjoining waters, as revealed by microsatellites
}

\author{
William F. Hutchinson ${ }^{1, *}$, Gary R. Carvalho ${ }^{1}$, Stuart I. Rogers ${ }^{2}$ \\ ${ }^{1}$ Molecular Ecology and Fisheries Genetics Laboratory, Department of Biological Sciences, University of Hull, \\ Hull HU6 7RX, United Kingdom \\ ${ }^{2}$ CEFAS, Lowestoft Laboratory, Pakefield Road, Lowestoft, Suffolk NR33 0HT, United Kingdom
}

\begin{abstract}
Previous studies of cod Gadus morhua population structure in European continental waters using molecular genetic markers have indicated high dispersal and limited structuring, in contrast to many tagging studies. More sensitive genetic techniques, in the form of microsatellite analysis, were used to reanalyse the population structure through the specific targeting of mature fish on spawning grounds. Significantly greater levels of differentiation were found than in previous studies, supporting the presence of 4 genetically distinct populations within the North Sea: Bergen Bank, Moray Firth, Flamborough Head and Southern Bight. Gene flow between the southern North Sea and eastern English Channel is largely restricted to populations within the Southern Bight (southern North Sea) and Beachy Head (eastern English Channel). The spawning stock in the central English Channel (Start Point) remains distinct from those in the Celtic Sea, Outer Hebrides, and central and northern North Sea. No evidence of sub-structuring within the Irish and Celtic Seas was found, in contrast to previous genetic studies, although the populations remained divergent from that of the Outer Hebrides. All European populations were significantly divergent from Canadian Scotian Shelf and Barents Sea (Bear Island) populations. The study indicates that the current fishery monitoring systems may need to be reassessed, particularly with respect to the North Sea, and highlights the value of using microsatellites combined with the targeting of spawning stocks to investigate subtle population structuring.
\end{abstract}

KEY WORDS: Gadus morhua $\cdot$ Population structure $\cdot$ North Sea $\cdot$ Irish Sea $\cdot$ Fishery management Microsatellite

Resale or republication not permitted without written consent of the publisher

\section{INTRODUCTION}

The recent development of significantly more sensitive molecular genetic markers has stimulated renewed interest in the analysis of population structure in marine fishes $\left(\mathrm{O}^{\prime}\right.$ Connell \& Wright 1997, Carvalho \& Hauser 1998), which have hitherto been characterised

*E-mail: w.f.hutchinson@biosci.hull.ac.uk by lower genetic diversity and differentiation when compared with anadromous and freshwater species (Ward et al. 1994). Such differences have been related to a presumed lack of isolating barriers, large population sizes and high mobility (Smith 1994, Carvalho \& Hauser 1998, Shaw et al. 1999b).

Microsatellites, in particular, are well suited for examining genetic structure in fish populations due to their selective neutrality and high mutation rates, affording greater allelic diversity and heterozygosities 


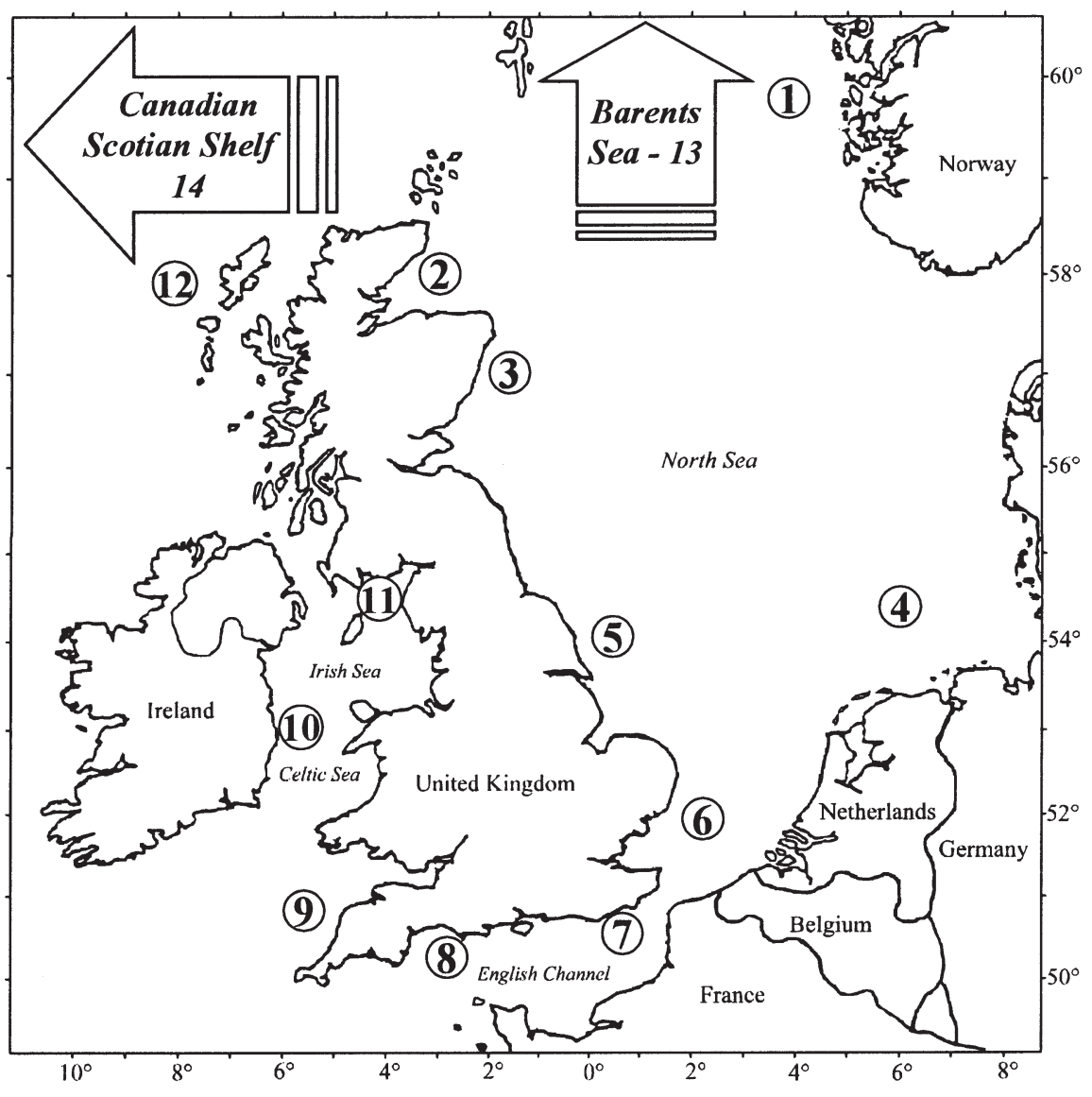

Fig.1. Map of the continental shelf of NW Europe showing sample locations: Bergen (1); Moray Firth (2); Aberdeen Ground (3); German Bight (4); Flamborough Head (5); Southern Bight (6); Beachy Head (7); Start Point (8); Trevose Head (9); West Isle of Man (10); East Isle of Man (11); Outer Hebrides (12). The Barents Sea (13); and the Canadian Scotian Shelf (14) are not shown here often approaching 90\% (O'Connell \& Wright 1997, Ruzzante 1998). Microsatellites are rapidly mutating, nuclear DNA regions, composed of tandem repeats of short nucleotide motifs of up to 6 nucleotides (Wright 1993). Recent applications of microsatellites have highlighted significant divergence between populations previously thought to be genetically homogenous (Bentzen et al. 1996, Ruzzante et al. 1996, 1998, O'Connell et al. 1998, Nesbø et al. 2000).

It has been suggested that some studies that found a lack of genetic differentiation may have done so because of inappropriate sampling or use of molecular markers (Carvalho \& Hauser 1998). For example, few previous studies of marine fishes have specifically targeted spawning stocks (Nesbø et al. 2000), and yet there is increasing evidence of genetically distinct populations mixing on feeding grounds and subsequently recruiting back to their natal spawning areas (Shaklee et al. 1990, Wirgin et al. 1997, Ruzzante et al. 2000a). Furthermore, sample sizes have often been too small, and the choice of molecular and statistical methods inappropriate (O'Connell \& Wright 1997, Ruzzante 1998, Waples 1998).

The Atlantic cod Gadus morhua is found in continental shelf waters throughout the North Atlantic. It is a key species, forming the third most important piscine predator (Macer \& Easey 1988), and plays a central role in ecosystem stability. Furthermore, it is a highly valued commercial resource, comprising a significant part of the fish landed from the North Sea. Consequently, it has attracted substantial scientific interest since the turn of the century, and attempts at monitoring cod population dynamics have been extensive throughout its range. However, several populations have shown significant declines or complete collapses in recent years, which have been frequently linked to ineffective management (Myers et al. 1996, Serchuk et al. 1996, Cook et al. 1997).

Cod in European continental shelf waters have received little attention by marine geneticists since the early 1980s, and the current knowledge of population structure within the North Sea and the Irish Sea is based largely upon allozyme and blood protein studies (Sick 1965, Jamieson 1970, Jamieson \& Thompson 1972, Child 1988). Initial studies maintained that North Sea populations constituted a single homogenous stock, contradicting the results of tagging surveys (Bedford 1966). The Channel, Celtic Sea and Irish Sea have been little studied genetically, though Child (1988) found evidence of separate populations in the 
eastern and western Irish Sea. Growth rate data (Agnew 1988) support this theory, while tagging studies (Brander 1994 and references therein, Pawson 1995) have indicated the presence of separate populations to the west of Scotland, and within the eastern and western Channel.

This study presents an extensive genetic survey of North Atlantic cod in the European continental shelf waters (North Sea, English Channel, Celtic Sea and Irish Sea), using the Barents Sea and the Canadian Scotian Shelf as outgroup comparisons. In contrast to many past studies, spawning adults were specifically targeted on the spawning grounds. Furthermore, the present study represents the first in-depth analysis using microsatellite markers of cod stock structure in the waters surrounding the UK.

\section{MATERIALS AND METHODS}

Sample collection. The main cod spawning grounds in the waters surrounding the UK were targeted, comprising 12 sites within the North Sea, Celtic Sea, Irish Sea and north-western Scotland (Fig. 1). Samples were also collected from the Barents Sea (Bear Island) and the Canadian Scotian Shelf (Banquereau Bank, Browns Bank) for macrogeographic or 'out-group' comparisons. Wherever possible, samples were collected during research cruises ( 7 out of 14 samples), with the remainder being taken from fish markets directly after landing. Samples were obtained from local inshore boats, which were known to be fishing the main cod spawning grounds. All sampling took place during the spawning season, and running or spent fish were targeted when data were available on the spawning status. Since most fish sampled at the markets were gutted prior to landing, and hence spawning status was unknown, total length measurements were taken to estimate age and likely maturity from catch data (Daan 1974). Consequently, only fish over $70 \mathrm{~cm}$ in total length were used for genetic analysis. Pectoral fin clippings were taken and preserved in $90 \%$ ethanol for subsequent DNA extraction. Samples of 50 fish were collected at each of the 14 locations.

DNA extraction. DNA was extracted from the tissue samples following a procedure based on Taggart et al. (1992). Briefly, pieces of tissue of approximately $100 \mu \mathrm{l}$ in volume were digested for $3 \mathrm{~h}$ in $500 \mu \mathrm{l}$ of extraction buffer containing $0.1 \mathrm{M}$ Tris $\mathrm{HCl}, 10 \mathrm{mM}$ EDTA, $0.1 \mathrm{M}$ $\mathrm{NaCl}, 2 \%$ SDS and $0.1 \mathrm{mg}$ Proteinase $\mathrm{K} \mathrm{ml}^{-1}$. The cellular debris was removed using phenol/chloroform extraction, and the DNA precipitated with absolute ethanol. Finally, DNA was dissolved in $50 \mu$ l of doubledistilled water and stored at $-20^{\circ} \mathrm{C}$.
Microsatellite amplification and screening. Five dinucleotide (GT repeat) cod microsatellite loci were employed in this study, to give a range of allelic diversity and heterozygosity. Two loci, GMO2 and GMO132, were obtained from Brooker et al. (1994) and PCR-amplified according to the conditions therein. Three additional loci, GADM1, GADM2 and GADM3, were developed using the PIMA technique described in Lunt et al. (1999) (sequences available in GeneBank, Accession nos. AF263940, AF263941, AF263942, http:// www.ncbi.nlm.nih.gov/). Reaction mixes of $15 \mu \mathrm{l}$ PCR were prepared for these 3 loci, containing 20 ng template DNA, $1 \times \mathrm{NH}_{4}$ reaction buffer (Bioline), $1.5 \mathrm{mM}$ $\mathrm{MgCl}_{2}, 200 \mu \mathrm{M} d \mathrm{dNPs}_{\mathrm{s}}, 250 \mathrm{nM}$ of each primer (1 primer end-labelled with Cy5 fluorescent dye) and 0.2 units Taq polymerase (Bioline). GADM1 was PCRamplified using 1 cycle of $95^{\circ} \mathrm{C}$ for $90 \mathrm{~s} ; 35$ cycles of $94^{\circ} \mathrm{C}$ for $45 \mathrm{~s}, 51^{\circ} \mathrm{C}$ for $30 \mathrm{~s}$ and $72^{\circ} \mathrm{C}$ for $30 \mathrm{~s}$; whilst GADM3 and GADM2 were amplified using 1 cycle of $95^{\circ} \mathrm{C}$ for $90 \mathrm{~s} ; 5$ cycles of $94^{\circ} \mathrm{C}$ for $45 \mathrm{~s}, 61^{\circ} \mathrm{C}$ for $30 \mathrm{~s}$ and $7^{\circ} \mathrm{C}$ for $30 \mathrm{~s}$; and finally 25 cycles of $94^{\circ} \mathrm{C}$ for $45 \mathrm{~s}, 60^{\circ} \mathrm{C}$ for $30 \mathrm{~s}$ and $72^{\circ} \mathrm{C}$ for $30 \mathrm{~s}$. Products were combined with internal size markers and electrophoresis undertaken on $6 \%$ polyacrylamide gels using a Pharmacia ALFexpress automatic sequencer (Amersham, UK). A series of standard samples were included in all runs to ensure consistency in scoring across gels. Products were sized using the accompanying Fragment Manager software.

Data analysis. Observed $\left(H_{\mathrm{o}}\right)$ and expected $\left(H_{\mathrm{e}}\right)$ heterozygosities were estimated using GENEPOP v. 3.1d (Raymond \& Rousset 1995). Departures from HardyWeinberg equilibrium in the form of a deficiency or excess of heterozygotes were tested with GENEPOP using the Markov chain method (3000 iterations) to obtain unbiased estimates of the exact p-value (Guo \& Thompson 1992). The analysis included testing for linkage disequilibrium in the form of independence of loci using the Markov chain method (3000 iterations) and Fisher's Exact test (Haldane 1954).

Genic population differentiation was estimated using GENEPOP by comparing allele frequencies between samples using Fisher's Exact test. This method makes no assumptions about mutation models.

The associated mutational processes involved in microsatellite evolution are not fully understood, and there is still considerable debate concerning the appropriate choice of mutation models and associated statistical methods (Jarne \& Lagoda 1996, O'Connell \& Wright 1997). Briefly, the models are based upon 2 general forms of evolution, the Infinite Allele Model (IAM), whereby every mutation gives rise to a new allele, and the Stepwise Mutation Model (SMM), whereby mutations occur via the loss or gain of a repeat unit with an associated ancestry. The SMM, in 
contrast to the IAM, assumes that mutations may lead to an allelic state which is already present (homoplasy). Empirical evidence suggests that mutations may follow either model, or a combination of both, and thus it has been suggested that both measures should be calculated (Jarne \& Lagonda 1996, Goodman 1997 , Shaw et al. 1999a) for comparison. Therefore, 2 mutation-model-based fixation indices or F-statistics (Wright 1965) were used to assess the distribution of genetic variation within and among samples. The parameter $\theta$, an IAM measure of $F_{\mathrm{ST}}$ (Weir \& Cockerham 1984), was compared with $\rho$ (Goodman 1997), an SMM estimate of Slatkin's $R_{\mathrm{ST}}$ (Slatkin 1995), which adjusts for differences in sample size and allele size variances among loci, using Arlequin Ver. 1.1 (Schneider et al. 1997) and RST-CALC Ver. 2.2 (Goodman 1997) respectively. Significance levels were calculated using 1000 permutations. Sequential Bonferroni (Rice 1989) adjustments were calculated to account for multiple simultaneous tests.

Two measures of genetic distance, Nei's (1972) $D_{\mathrm{s}}$ (IAM) and Goldstein et al.'s (1995) $\Delta \mu^{2}$ (SMM), were calculated to provide an estimate of evolutionary relationship between samples, using PHYLIP v. 3.5c (Felsenstein 1989), and RST-CALC ver 2.2 (Goodman 1997) respectively. The 2 measures were log-transformed and plotted against logged geographic distance in kilometres to assess whether isolation by distance influenced the levels of divergence seen between the populations of cod. Mantel tests (1000 permutations) were used to test levels of significance.

\section{RESULTS}

\section{Hardy-Weinberg equilibrium and population diversity}

The 5 microsatellite loci showed varying degrees of allelic diversity (Table 1), ranging from 8 alleles in locus GADM1 to 54 alleles in locus GADM3, and with mean observed heterozygosities of 0.47 to 0.92 , respectively. Mean observed heterozygosities across loci within samples ranged from 0.68 for the Barents Sea to 0.84 for the Start Point and Outer Hebrides samples, while mean allelic diversity ranged from 12.4 in the Barents Sea to 20.2 in the Start Point sample. Levels of allelic diversity were largely comparable within European continental waters, and noticeably lower in the Barents Sea and Canadian samples. Although 4 samples showed evidence of heterozygote deficiency at the $\mathrm{p}<0.05$ or 0.01 level (Flamborough Head with GADM1, German Bight with GADM3, Trevose Head with GADM2 and Barents Sea with GADM2), there was no direct correlation with specific loci or samples, and none remained significant when adjusted for table-wide significance using the sequential Bonferroni procedure (Rice 1989). No evidence of linkage disequilibrium was observed at any of the 5 loci investigated, thus allowing allelic variation at all loci to be treated as independent.

\section{Population differentiation and structure}

Pairwise Exact tests of genic differentiation between all 14 populations of Gadus morhua indicated varying degrees of structuring (Table 2). Allele frequencies within the Barents Sea and Canadian samples were significantly divergent ( $p<0.001)$ from all other samples, while the Bergen and Moray Firth samples differed from all other samples to a lesser degree, with levels of significance ranging from $\mathrm{p}<0.001$ to nonsignificance (Flamborough Head, Outer Hebrides, and German Bight). Furthermore, evidence of a significant divergence was identified between the Southern Bight and both the East and West Isle of Man samples ( $\mathrm{p}<$ 0.05 and $p<0.01$, respectively), and between Aberdeen Ground and Start Point ( $\mathrm{p}<0.05)$.

Analysis of genetic variation among samples using the more sensitive fixation indices, $\theta F_{\mathrm{ST}}$ and $\rho R_{\mathrm{ST}}$, also indicated significant heterogeneity (Table 2), although not always in agreement with genic differentiation estimates. Generally, $\theta F_{\mathrm{ST}}$ and $\rho R_{\mathrm{ST}}$ values differed little, although genic differentiation significance levels were more likely to be in agreement with $\theta F_{\mathrm{ST}}$

Table 1. Gadus morhua. Mean allelic diversity, total number of alleles, allelic range, and mean observed and expected heterozygosity across the 14 populations of Atlantic cod analysed at 5 microsatellite loci. A copy of allelic frequencies for all samples across the 5 loci can be obtained from the authors

\begin{tabular}{|lccccc|}
\hline & GMO2 & GADM1 & GMO132 & GADM3 & GADM2 \\
\hline Mean allelic diversity & 12.8 & 4.9 & 19.0 & 30.7 & 21.2 \\
Total number of alleles & 22 & 8 & 46 & 54 & 33 \\
Allelic range (base pairs) & $104-146$ & $123-137$ & $107-227$ & $96-228$ & $106-190$ \\
Mean observed heterozygosity & 0.83 & 0.47 & 0.83 & 0.92 & 0.90 \\
Mean expected heterozygosity & 0.85 & 0.47 & 0.88 & 0.96 & 0.92 \\
\hline
\end{tabular}




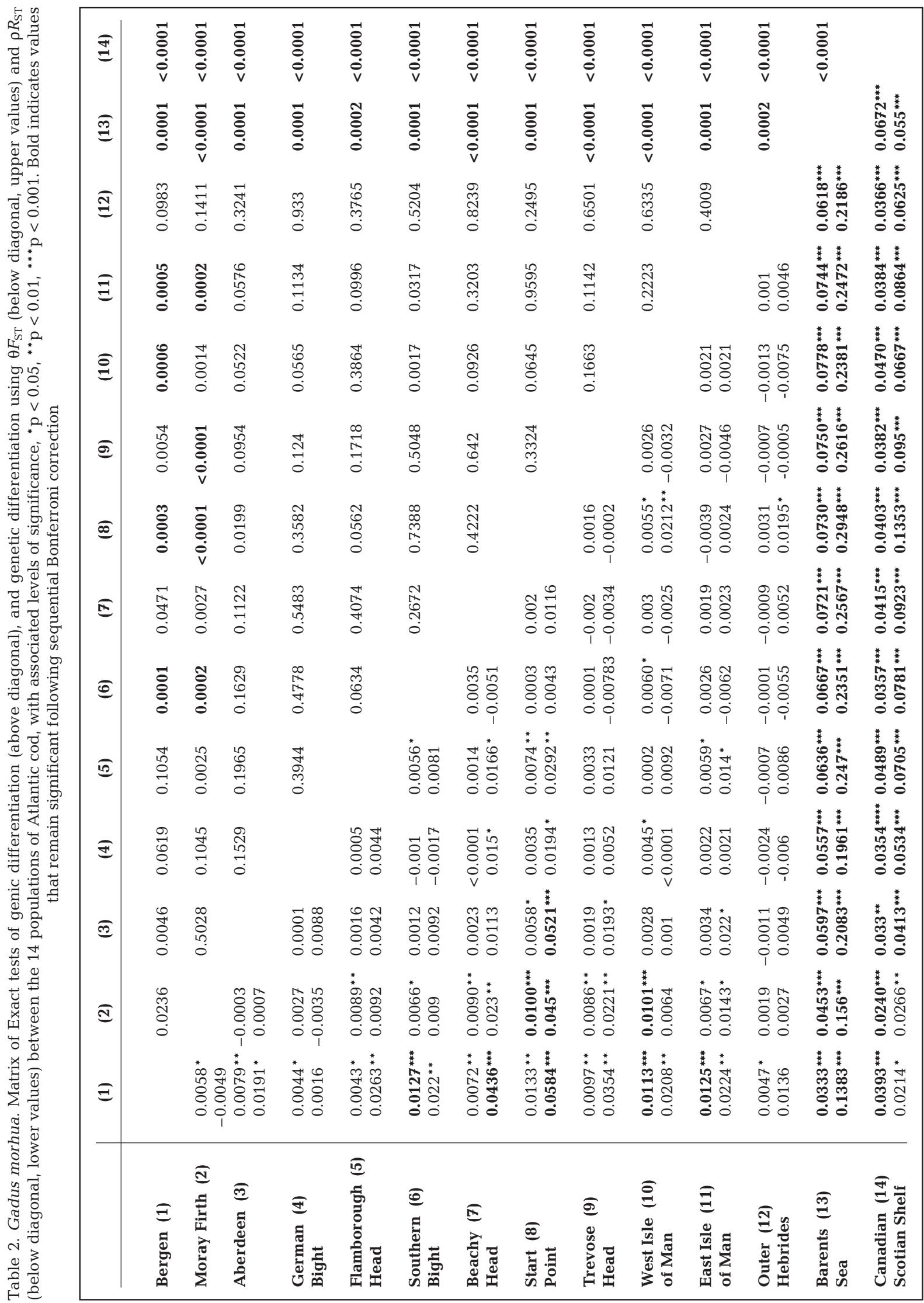


than $\rho R_{\mathrm{ST}}$ values, as predicted from assumptions inherent in the respective algorithms. Barents Sea and Canadian samples remained significantly divergent from all other samples, although p-values for 2 pairwise comparisons fell below the $\mathrm{p}<0.001$ level (Canadian versus Moray Firth and Bergen). Measures of $\theta F_{\mathrm{ST}}$ largely confirmed that Bergen and Moray Firth were significantly divergent from the other samples, and frequently showed higher levels of significance than $\rho R_{\mathrm{ST}}$

Furthermore, both $\rho R_{\mathrm{ST}}$ and $\theta F_{\mathrm{ST}}$ estimates indicated significant genetic divergences $(p<0.01$ and $p<0.05$, respectively) between Flamborough Head and Start Point, and Flamborough Head and East Isle of Man. There were an additional 8 cases in which either $\rho R_{\mathrm{ST}}$ or $\theta F_{\mathrm{ST}}$ indicated a reduced but significant $(\mathrm{p}<0.05)$ divergence between regions. Collectively, the data suggest restricted gene flow between the North Sea, Irish Sea and Channel.

Applying sequential Bonferroni correction to these tests frequently caused p-values lower than 0.001 to become non-significant, typifying a Type 2 error of rejecting significant results due to excessive numbers of pairwise comparisons. It has been stated (Sachs 1980, Altman 1991) that the Bonferroni method is unsuitable for cases in which $>5$ comparisons are being made, and that above this level the method becomes highly conservative. Consequently, in the present study, values that remained significant after sequential Bonferroni were highlighted in bold (Table 2), indicating that although caution may be required in interpreting the non-highlighted significant results, they should not be rejected.

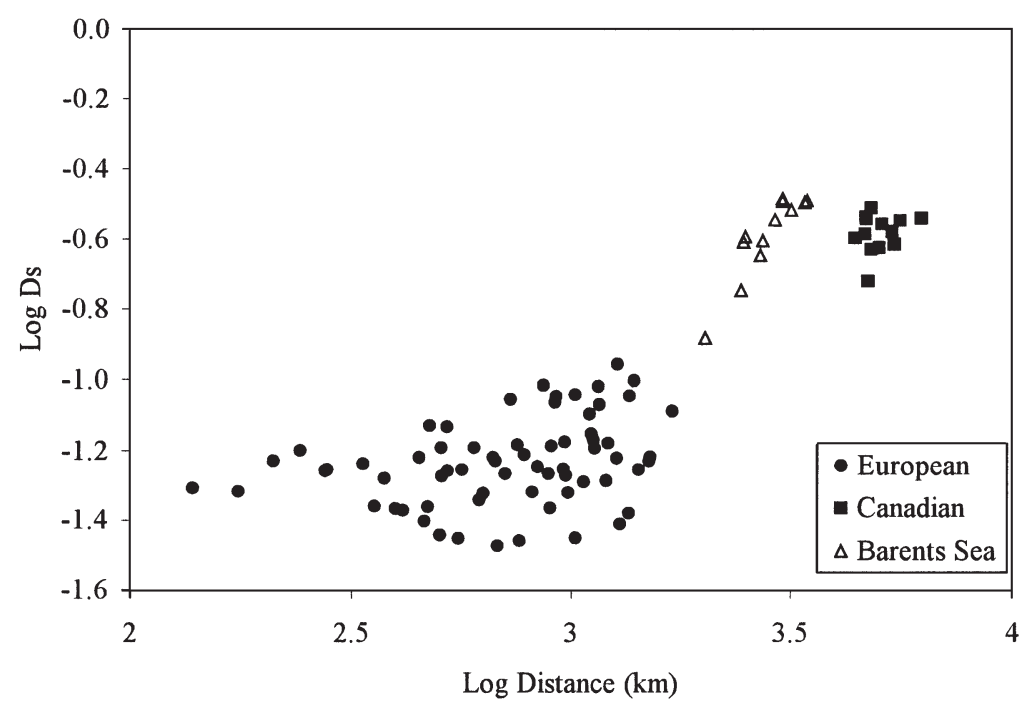

Fig. 2. Isolation-by-distance plots of log-transformed geographical distance between sample sites $(\mathrm{km})$ against log-transformed $D_{\mathrm{s}}$ (Nei 1972) values, separated into Canadian, Barents Sea and European pairwise comparisons

\section{Genetic distance}

Nei's (1972) standard distance $D_{\mathrm{s}}$ and Goldstein et al.'s (1995) $\Delta \mu^{2}$ were calculated for all pairwise comparisons. The 2 measures of genetic distance, $D_{\mathrm{s}}$ and $\Delta \mu^{2}$, were log-transformed and plotted against logtransformed geographic distance in kilometres (Fig. 2). The 2 measures gave comparable plots, and hence only $D_{\mathrm{s}}$ is shown in the figure.

When all populations are included, the correlation between geographical and genetic distance $\left(D_{\mathrm{s}}: \mathrm{r}^{2}=\right.$ $0.89 ; \Delta \mu^{2}: \mathrm{r}^{2}=0.53$ ) was shown to be highly significant $\left(D_{\mathrm{s}}: \mathrm{p}<0.001 ; \Delta \mu^{2}: \mathrm{p}<0.01\right.$ - Mantel tests), suggesting that isolation by distance may be an important factor on a macrogeographic scale. The $\mathrm{r}^{2}$ values decline, but are still significant within European waters $\left(D_{\mathrm{s}}: \mathrm{r}^{2}=\right.$ $\left.0.38, \mathrm{p}<0.001 ; \Delta \mu^{2}: \mathrm{r}^{2}=0.39, \mathrm{p}<0.001\right)$, and on a finer scale within the North Sea $\left(D_{\mathrm{s}}: \mathrm{r}^{2}=0.21, \mathrm{p}<0.04\right)$. Distance plays an important role in isolating populations in the north eastern Atlantic from the Barents Sea, as indicated by the high $\mathrm{r}^{2}$ values $\left(D_{\mathrm{s}}: \mathrm{r}^{2}=0.82 ; \Delta \mu^{2}: \mathrm{r}^{2}=\right.$ $0.85)$, in contrast to the Canadian pairwise comparisons in which geographic distance accounts for a negligible proportion of the variation in genetic differentiation $\left(D_{\mathrm{s}}: \mathrm{r}^{2}=0.051 ; \Delta \mu^{2}: \mathrm{r}^{2}=0.034\right)$.

\section{DISCUSSION}

\section{The utility of the approach employed}

The present work adds to a recent trend in which microsatellites have identified sub-structuring where earlier techniques based upon protein assays (e.g. allozymes) and mitochondrial DNA indicated homogeneity. It is increasingly apparent that the non-coding nature and high mutation rates of microsatellites renders them highly suited to identifying the weak sub-structuring that is typical of many marine teleosts. However, recent publications (O'Connell \& Wright 1997, Shaw et al. 1999a) have stated that loci that are too polymorphic may be unsuitable for assessing genetic differentiation. Ruzzante (1998) used cod microsatellite data to demonstrate empirically that low and unequal sample sizes combined with high allelic variability can increase variance in estimates of genetic distances and population structuring. Ruzzante recommended equal sample sizes of at least 50 , as employed in the present study, to obtain precise and accurate estimates. 
This study is unique in providing the first comprehensive genetic survey of cod Gadus morhua within the European continental shelf waters, using microsatellites. Additionally, unlike many genetic studies on marine teleosts, samples were composed of mature fish collected on the spawning grounds during the spawning season, thus ensuring that populations were sampled at a time of highest genetic stock integrity. This is of particular importance in this study as tagging results indicate that cod populations undergo seasonal migrations between spawning and feeding grounds, potentially mixing with other genetically distinct populations (Daan 1978, Brander 1994, Pawson 1995).

\section{Macrogeographic patterns}

Past studies of genetic divergence in cod stocks across the North Atlantic have often provided contradictory results. Blood proteins, allozymes (de Ligny 1969 and references therein, Cross \& Payne 1976, Mork et al. 1985) and microsatellite data (Bentzen et al. 1996) have indicated significant divergence between the eastern and western Atlantic populations, and between the Barents Sea and Canadian stocks, in contrast to mitochondrial studies (Smith et al. 1989, Árnason \& Pálsson 1996).

The present study corroborates the results of Bentzen et al. (1996) indicating a highly significantly divergence $\left(\theta F_{\mathrm{ST}}: \mathrm{p}<0.001 ; \rho R_{\mathrm{ST}}: \mathrm{p}<0.001\right)$ between the Canadian and Barents Sea samples, and between these and the populations resident in European waters. Logarithmic plots of genetic distance estimates $D_{\mathrm{s}}$ and $\Delta \mu^{2}$ also indicate evidence of isolation by distance at 3 successive levels with differing $\mathrm{r}^{2}$ values. Firstly, on a trans-oceanic scale $\left(D_{\mathrm{s}}: \mathrm{r}^{2}=0.05, \Delta \mu^{2}: \mathrm{r}^{2}=0.03\right)$, Canadian cod are unlikely to extend to European continental waters, and thus all the European samples are equally divergent from the Canadian populations; secondly on an intermediate scale $\left(D_{\mathrm{s}}: \mathrm{r}^{2}=0.82, \Delta \mu^{2}: \mathrm{r}^{2}=\right.$ $0.85)$, isolation by distance plays an important role between the Arctic ocean and Europe; and, finally, on the continental shelf around the UK $\left(D_{\mathrm{s}}: \mathrm{r}^{2}=0.38, \Delta \mu^{2}\right.$ : $\left.r^{2}=0.39\right)$ the correlation between geographic and genetic distance is weaker.

Interestingly, the Barents Sea sample is substantially more divergent than the more geographically distinct Canadian sample, suggesting the operation of processes other than isolation alone. Similar marked divergence has been observed in cod (Dahle 1991, Bentzen et al. 1996), blue whiting Micromesistius poutassou (Giæever \& Stien 1998), haddock Melanogrammus aeglefinus (Giæver \& Forthun 1999) and herring Clupea harengus (Shaw et al. 1999b) from the Barents Sea. It is also noteworthy that the Barents Sea samples exhibited a significantly lower allelic diversity and heterozygosity than all other samples (mean allelic diversity of 12.4 versus 18.1; mean observed heterozygosity of 0.68 versus 0.8), particularly at locus GMO132 (5 versus 19 alleles), reflecting a trend which has been seen in other microsatellite studies of cod (Dahle 1995, Bentzen et al. 1996). It has been suggested that differences in water temperature between the Barents Sea and more southerly waters may lead to localised adaptation or physical isolation (Shaw et al. 1999b). Additionally, the differentiation could also reflect a post-glacial colonisation process, similar to the reduced diversity seen in more northerly populations documented in terrestrial species (Hewitt 1999), or the relic of a severe population decline resulting in a genetic bottleneck.

\section{Localised geographic patterns}

The results indicate that there is significantly more genetic sub-structuring within the European continental shelf waters than previously detected, often confirming the patterns derived from extensive tagging studies and the analysis of catch statistics.

All previous genetic studies maintained that cod in the North Sea are genetically homogenous and, consequently, all later genetic studies have treated the North Sea cod as a single population. However, extensive tagging data (Bedford 1966, Anonymous 1971, Holden \& Raitt 1974) and evidence of the Wahlund effect (a process whereby samples composed of $>1$ genetically distinct population show a heterozygote deficiency) in blood protein studies (Jamieson \& Thompson 1972) have indicated the presence of up to 3 regional groupings within the North Sea.

The results herein contradict the hypothesis that the North Sea is composed of a single homogenous stock; microsatellite data indicate the existence of at least 3 to 4 genetically divergent populations, with possible evidence of further weak sub-structuring. F-statistics and genetic distance measures indicate significant divergence between Bergen and the rest of the North Sea $\left(\theta F_{\mathrm{ST}}\right.$ : all $\mathrm{p}$-values $\leq 0.05 ; \rho R_{\mathrm{ST}}$ : 11 of $14 \mathrm{p}$-values $\left.\leq 0.05\right)$. Furthermore, there is also evidence of a weaker divergence between Moray Firth and the populations resident within the central and southern North Sea, in particular Flamborough Head $\left(\theta F_{\mathrm{ST}}\right.$ : 0.0089, $\left.\mathrm{p}<0.01\right)$ and Southern Bight $\left(\theta F_{\mathrm{ST}}: 0.0066, \mathrm{p}<0.05\right)$. Flamborough Head is also seen to be divergent from Southern Bight $\left(\theta F_{\mathrm{ST}}: 0.0056, \mathrm{p}<0.05\right)$. Data are in line with the predictions that cod along the north-eastern Scottish coast are most likely to show evidence of genetic isolation, and that a cline of increasing divergence along the eastern English and Scottish coast might exist (Daan 1978). Moreover, data support the presence of distinct Flamborough Head and Southern Bight populations, 
as predicted by the ICES North Sea Roundfish Working Group (Anonymous 1971).

There have been no previous genetic studies of cod within the Channel, and the current knowledge is therefore based largely upon tagging work. Tagging data suggest that the eastern Channel forms a spawning ground for populations that remain in the Channel, and also for juvenile cod migrating into the southern North Sea (Pawson 1995). There is, however, a lack of evidence for adult cod recruiting back into the eastern channel to spawn. This limited migration is supported by the present study, which indicates that the populations resident off Beachy Head and within the Southern Bight are genetically similar. Furthermore, Beachy Head is found to be significantly divergent from Flamborough Head $\left(\rho R_{\mathrm{ST}}: 0.0166, \mathrm{p}<0.05\right)$ and German Bight $\left(\rho R_{\mathrm{ST}}: 0.015\right.$, $\mathrm{p}<0.05$ ), indicating that migration into the North Sea is restricted to the Southern Bight area.

Tagging results (Pawson 1995) indicate limited migration between the eastern Channel, western Channel and Celtic Sea. Furthermore, recruitment levels and age compositions of landings between the eastern and western Channel occasionally differ. Although $F$-statistic estimates of divergence given here are not significant (at $\mathrm{p}<0.05$ level) within the Channel, Start Point is found to be highly divergent from neighbouring populations in the North and Irish Seas, suggesting that although the divergence is non-significant locally, it is highly significant on a larger scale. These results corroborate circumstantial evidence from south Devon fishing communities, which suggests that the cod off Start Point seldom move out of the western English Channel (Pawson 1995).

Evidence for the presence of at least 2 distinct stocks within the Irish Sea and Celtic Sea includes: allozyme studies (Child 1988); evidence of the Wahlund effect in haemoglobin data (Brander 1975); tagging data (Brander 1975 and references therein, Pawson 1995); and bimodal distributions of total lengths in Northern Ireland catch data (Agnew 1988). However, the present study did not identify any significant (at $\mathrm{p}<0.05$ level) sub-structuring within the Irish and Celtic Sea samples, a pattern which is consistent with the strong correlations seen in recruitment trends in the Celtic and Irish Sea (Myers et al. 1995). Furthermore, the Outer Hebrides population differed little from populations in the Celtic and Irish Seas, although it was significantly divergent from the Start Point population $\left(R_{\mathrm{ST}}: 0.0195\right.$, $\mathrm{p}<0.05)$ in the western English Channel.

\section{Barriers to gene flow}

The question therefore remains as to what processes might initiate and maintain the degrees of divergence seen among the cod populations. Isolation by distance explains only 3 to $5 \%$ of the divergence between the Canadian population and others around Europe. This would correlate with an ancient divergence of the 2 regions, followed by subsequent expansion and divergence of the European populations, with the Atlantic Ocean forming a barrier to further significant gene flow.

In contrast, isolation by distance is clearly a dominant factor with respect to the Barents Sea and to a lesser degree within European waters. Oceanographic and behavioural factors may also influence levels of differentiation in European waters, particularly where geographically proximate populations show significant genetic divergence (e.g. Bergen and Moray Firth). Furthermore, other factors that may also reduce the correlation between geographic and genetic distance include: multi-directional gene flow around the UK; low resolving power of the genetic markers; violation of the stepping-stone model of migration upon which the 'isolation-by-distance' theory is based; and insufficient time for populations to reach equilibrium following colonisation (Hellberg 1994).

\section{Implications for fishery monitoring and future management}

Given the current precarious status of cod within the north-eastern Atlantic, and in particular the North Sea, measures need to be taken to conserve current stocks. Annual Total Allowable Catches (TAC) have been reduced in some management areas, and seasonal closures of select spawning grounds are to be applied in an attempt to reduce fishing mortality and enhance spawning stock levels. However, the present study also indicates that several of the current management units, which are assumed to be single stocks for the purposes of assessment, are in fact composed of several genetically distinct stocks. Thus the present amalgamation of data from different biological stocks may hide a disproportionate decline of the more vulnerable, which may require separate monitoring and management policies to remain sustainable. Although a system of regular sampling of landings of cod at ports throughout Europe already exists, it is likely that outside the spawning season, catches will be composed of mixed stocks. There would therefore be a need to identify the relative contributions from putative stocks, such that they can be monitored independently. Indeed, Ruzzante et al. (2000b), working on stock complexes of cod in the north-western Atlantic have demonstrated the efficacy of a mixed-stock-analysis approach based on 6 polymorphic microsatellite loci. It was possible not only to estimate the proportion of cod contributions from 
various stock components, but also to demonstrate temporal stability of structuring over a 2 yr period. However, incorporating this information into an effective and realistic management policy would be difficult, without resorting to the large-scale closure of fisheries. In summary, the present study contradicts earlier work, which indicated that cod populations in the North Sea were genetically homogenous, by identifying 3 to 4 genetically divergent populations resident off Bergen, within the Moray Firth, off Flamborough Head and within the Southern Bight. Furthermore, it indicates the presence of a genetically distinct population off the southern Cornish coast. However, in contrast to past genetic studies, no evidence of significant structuring is found within the Irish and Celtic Seas. Much of this data is in agreement with previous tagging work.

The Barents Sea is seen to be highly divergent from the other populations resident in the waters surrounding the UK, and significantly less diverse, suggesting a possible barrier to gene flow, recent post-glacial colonisation or a genetic bottleneck.

The detection of a higher degree of genetic structuring compared to past genetic studies most likely arises from a combination of using more sensitive microsatellite markers and the specific targeting of spawning fish on spawning grounds. The current UK fishery monitoring system may need to be reassessed in order to take account of the additional sub-structuring detected.

Acknowledgements. We are indebted to the following people who made this study possible by helping with the collection of samples: Michael Armstrong, Don Aves, John Casey, John Cole, Doug Cook, Ken Coull, Craig Davis, Siegfried Ehrich, Fred Frettsome, Simon Hadfield, Henk Heessen, Paul Johnson, Phil Kunzlik, Ken Meachin, Alan Mutch, Andrew Newton, John Nichols, Haakon Otteraa, Terry Pearson, Sandy Rob, Yves Verin, Wolfgang Weber, Kai Wieland, Neil Wellum and Dave Weetman. Thanks are also due to John Casey, Mike Pawson and the anonymous referees for valuable comments on the manuscript. The study was funded by a PhD scholarship from Hull University and a small research grant from the Fisheries Society of the British Isles.

\section{LITERATURE CITED}

Agnew DJ (1988) Evidence for the existence of two populations of Irish Sea cod (Gadus morhua L.) from consideration of growth rates. ICES/Demersal Fish Comm G:65:1-10. International Council for the Exploration of the Sea, Copenhagen

Altman DG (1991) Practical statistics for medical research. Chapman and Hall, London

Anonymous (1971) Report by the North Sea Roundfish Working Group on North Sea cod. ICES/Demersal Fish Comm F:5:1-35. International Council for the Exploration of the Sea, Copenhagen

Árnason E, Pálsson S (1996) Mitochondrial cytochrome $b$
DNA sequence variation of Atlantic cod Gadus morhua, from Norway. Mol Ecol 5:715-724

Bedford BC (1966) English cod tagging experiments in the North Sea. ICES/Demersal Fish Comm G:9:1-9. International Council for the Exploration of the Sea, Copenhagen

Bentzen P, Taggart CT, Ruzzante DE, Cook D (1996) Microsatellite polymorphism and the population structure of Atlantic cod (Gadus morhua) in the northwest Atlantic. Can J Fish Aquat Sci 53:2706-2721

Brander KM (1975) The population dynamics and biology of cod (Gadus morhua) in the Irish Sea. PhD thesis, University of East Anglia, Norwich

Brander KM (1994) Spawning and life history information for North Atlantic cod stocks. ICES Coop Res Rep 205:64-83 International Council for the Exploration of the Sea, Copenhagen

Brooker A, Cook D, Bentzen P, Wright J, Doyle R (1994) Organization of microsatellites differs between mammals and cold-water teleost fishes. Can J Fish Aquat Sci 51: 1959-1966

Carvalho GR, Hauser L (1998) Advances in molecular analysis of fish population structure. Ital J Zool 65:21-33

Child AR (1988) Population genetics of cod (Gadus morhua (L)), haddock (Melanogrammus aeglefinus (L)), whiting (Merlangius merlangus (L)) and saithe (Pollachius virens (L)). MAFF Fish Res Technol Rep 87:1-27

Cook RM, Sinclair A, Stefánsson G (1997) Potential collapse of North Sea cod stocks. Nature 385:521-522

Cross TF, Payne RH (1976) The use of protein polymorphism to distinguish cod stocks. ICES/Demersal Fish Comm F:25 International Council for the Exploration of the Sea, Copenhagen

Daan N (1974) Growth of North Sea cod, Gadus morhua. Neth J Sea Res 8:27-48

Daan N (1978) Changes in cod stocks and cod fisheries in the North Sea. Rapp P-V Reun Cons Int Explor Mer 172:39-57

Dahle G (1991) Cod, Gadus morhua L., populations identified by mitochondrial DNA. J Fish Biol 38:295-303

Dahle G (1995) Genetic structure of the North-East Atlantic cod (Gadus morhua), and appraisal of different molecular techniques. PhD thesis, University of Bergen, Norway

de Ligny W (1969) Serological and biochemical studies on fish populations. Oceangr Mar Biol Annu Rev 7:411-513

Felsenstein J (1989) PHYLIP - Phylogeny Inference Package (3.2 v). Cladistics 5:164-166

Giæver M, Forthun J (1999) A population genetic study of haddock (Melanogrammus aeglefinus) in Northeast Atlantic wafers based on isozyme data. Sarsia 84:89-98

Giæver M, Stien J (1998) Population genetic substructure in blue whiting based on allozyme data. J Fish Biol 52: 782-795

Goldstein DBA, Linares AR, Cavalli-Sforza LL, Feldman MW (1995) Genetic absolute dating based on microsatellites and modern human origens. Proc Natl Acad Sci USA 92: 6723-6727

Goodman SJ (1997) RST Calc: a collection of computer programs for calculating estimates of genetic differentiation from microsatellite data and determining their significance. Mol Ecol 6:881-885

Guo SW, Thompson EA (1992) Performing the Exact test of Hardy-Weinberg proportion for multiple alleles. Biometrics 48:361-372

Haldane JBS (1954) An Exact test for randomness of mating. J Genetics 52:631-635

Hellberg ME (1994) Relationships between inferred levels of gene flow and geographic distance in a philopatric coral Balanophylla elegans. Evolution 48:1829-1854 
Hewitt GM (1999) Post-glacial re-colonisation of European biota. Biol J Linn Soc 68:87-112

Holden MJ, Raitt DFS (1974) Manual of fisheries science, Part 2. FAO Fish Tech Pap 115:1-214

Jamieson A (1970) Cod transferrins and genetic isolates. In: Proc 11th Europ Conf on animal blood groups and biochemical polymorphism. Dr. W. Junk, The Hague, p 533-538

Jamieson A, Thompson D (1972) Blood proteins in North Sea cod (Gadus morhua L.). In: Kovacs G, Papp M (eds) Proc 12th Euro Conf on animal blood groups and biochemical polymorphism. Dr. W. Junk, The Hague, p 585-591

Jarne P, Lagoda PJL (1996) Microsatellites, from molecules to populations and back. Trends Ecol Evol 11:424-429

Lunt DH, Hutchinson WF, Carvalho GR (1999) An efficient method for PCR-based isolation of microsatellite arrays (PIMA). Mol Ecol 8:891-894

Macer T, Easey MW (1988) North Sea cod and the English fishery. Laboratory Leaflet No. 61, MAFF, Lowestoft

Mork J, Ryman N, Ståhl G, Utter F, Sundes G (1985) Genetic variation in Atlantic cod (Gadus morhua) throughout its range. Can J Fish Aquat Sci 42:1580-1587

Myers R, Mertz G, Barrowman N (1995) Spatial scales of variability in cod recruitment in the North Atlantic. Can J Fish Aquat Sci 52:1849-1862

Myers RA, Hutchings JA, Barrowman NJ (1996) Hypothesis for the decline of cod in the North Atlantic. Mar Ecol Prog Ser 138:293-308

Nei M (1972) Genetic distances between populations. Am Nat 106:283-292

Nesbø CL, Rueness EK, Iversen SA, Skagen DW, Jakobsen KS (2000) Phylogeography and population history of Atlantic mackerel (Scomber scombrus L.): a genealogical approach reveals genetic structuring among the eastern Atlantic stocks. Proc R Soc Lond B Biol Sci 267:281-292

O'Connell M, Wright JM (1997) Microsatellite DNA in fishes. Rev Fish Biol Fish 7:331-363

O'Connell M, Dillon MC, Wright JM, Bentzen P, Merkouris S, Seeb J (1998) Genetic structuring among Alaskan Pacific herring (Clupea pallasi) populations identified using microsatellite variability. J Fish Biol 53:150-163

Pawson MG (1995) Biogeographical identification of English Channel fish and shellfish stocks. MAFF Fish Res Technol Rep 99:28-30

Raymond M, Rousset F (1995) GENEPOP - population genetics software for Exact tests and ecumenicism (1.2 v). J Hered 86:248-249

Rice WR (1989) Analysing tables of statistical tests. Evolution 43:223-225

Ruzzante DE, Taggart CT, Cook D, Goddard S (1996) Genetic differentiation between inshore and offshore Atlantic cod (Gadus morhua) off Newfoundland: microsatellite DNA variation and antifreeze level. Can J Fish Aquat Sci 53: 634-645

Ruzzante DE, Taggart CT, Cook D (1998) A nuclear DNA basis for shelf- and bank-scale population structure in northwest Atlantic cod (Gadus morhua): Labrador to Georges Bank. Mol Ecol 7:1663-1680

Ruzzante DE (1998) A comparison of several measures of genetic distance and population structure with microsatellite data: bias and sampling variance. Can J Fish Aquat Sci 55:1-14

Editorial responsibility: Otto Kinne (Editor)

Oldendorf/Luhe, Germany
Ruzzante DE, Wroblewski JS, Taggart CT, Smedbol RK, Cook D, Goddard SV (2000a) Bay-scale population structure in coastal Atlantic cod in Labrador and Newfoundland, Canada. J Fish Biol 56:431-447

Ruzzante DE, Taggart CT, Cook D, Lang S (2000b) Mixedstock analysis of Atlantic cod near the Gulf of St. Lawrence based on microsatellite DNA. Ecol Appl 10: 1090-1108

Sachs L (1980) Statistische Methoden: Planung und Auswertung. Springer-Verlag, Berlin

Schneider S, Kueffer J, Roessli D, Excoffier L (1997) Arlequin: a software for population genetic data analysis $(1.1 \mathrm{v})$. University of Geneva, Switzerland

Serchuk FM, Kirkegaard E, Daan N (1996) Status and trends of the major roundfish, flatfish, and pelagic fish stocks in the North Sea: a thirty-year overview. ICES J Mar Sci 53: 1130-1145

Shaklee JB, Phelps SR, Salini J (1990) Analysis of fish stock structure and mixed-stock fisheries by electrophoretic characterisation of allelic isozymes. In: Whitmore DH (ed) Electrophoretic and isoelectric focusing techniques in fisheries management. CRC Press, Boca Raton, FL

Shaw PW, Pierce GJ, Boyle PR (1999a) Subtle population structuring in a highly vagile marine invertebrate, the veined squid Loligo forbesi, demonstrated with microsatelite DNA markers. Mol Ecol 8:407-417

Shaw PW, Turan C, Wright JM, O'Connel M, Carvalho GR (1999b) Microsatellite DNA analysis of population structure in Atlantic herring (Clupea harengus), with direct comparison to allozyme and mtDNA RFLP analyses. Heredity 83:490-499

Sick K (1965) Haemoglobin polymorphism of cod in the North Sea and North Atlantic Ocean. Hereditas 54:59-73

Slatkin M (1995) A measure of population subdivision based on microsatellite allele frequencies. Genetics 139:457-462

Smith PJ (1994) Genetic diversity of marine fisheries resources. FAO Fish Tech Pap 344:1-45

Smith PJ, Birley AJ, Jamieson A, Bishop CA (1989) Mitochondrial DNA in the Atlantic cod, Gadus morhua: lack of genetic divergence between eastern and western populations. J Fish Biol 34:369-373

Taggart JB, Haynes RA, Prodohl PA, Ferguson A (1992) A simplified protocol for routine total DNA isolation from salmonid fishes. J Fish Biol 40:963-965

Waples RS (1998) Separating the wheat from the chaff: patterns of genetic differentiation in high gene flow species. J Hered 89:438-450

Ward RD, Woodwark M, Skibinski DOF (1994) A comparison of genetic diversity levels in marine, freshwater, and anadromous fishes. J Fish Biol 44:213-232

Weir BS, Cockerham CC (1984) Estimating F-Statistics for the analysis of population structure. Evolution 38:1358-1370

Wirgin II, Waldman JR, Maceda L, Stabile J, Vecchio VJ (1997) Mixed-stock analysis of Atlantic coast striped bass (Morone saxatilis) using nuclear DNA and mitochondrial DNA markers. Can J Fish Aquat Sci 54:2814-2826

Wright JM (1993) DNA fingerprinting of fishes. In: Hochachka PW, Mommsen T (eds) Biochemistry and molecular biology of fishes. Elsevier, Amsterdam, p 57-91

Wright S (1965) The interpretation of population structure by $F$-statistics with special regard to system of mating. Evolution 9:395-420

Submitted: September 18, 2000; Accepted: February 27, 2001

Proofs received from author(s): November 5, 2001 